\title{
REVIEWS
}

\section{MICROBIOLOGICAL SAFETY OF ORGANIC AND CONVENTIONAL FOODS}

\author{
Friedrich-Karl Lücke \\ Department of Nutritional, Food \& Consumer Studies, Fulda University of Applied Sciences, Leipziger Str. 123, \\ 36037 Fulda, Germany, e-mail: friedrich-karl.luecke@oe.hs-fulda.de
}

\begin{abstract}
Occasionally, concerns are expressed that use of organic manure in fertilisation, and free-ranging of livestock may result in higher loads of (mainly) enteric pathogens in organic food, and that avoiding the use of synthetic fungicides may increase the risk of mycotoxin contamination. Therefore, we compared published data on the levels of these hazards on some organically and conventionally produced foods. The results can be summarised as follows:

- There is no evidence that use of organic fertilizer in organic crops increases the prevalence of bacterial pathogens and/or of antibioticresistant bacteria on fresh produce.

- The prevalence of Campylobacter in live free-ranging poultry and of Toxoplasma in live free-ranging pigs tends to be somewhat higher than in animals kept conventionally indoors. However, this difference is hardly seen any more if carcasses and meat are analysed.

- Methicillin-resistant Staphylococcus aureus (MRSA) strains were found much more frequently in conventionally-produced raw food while the levels of extended-spectrum- $\beta$-lactamase-positive Escherichia coli (ESBL-E. coli) were reported as similar on somewhat lower on organic raw food.

- Most studies found lower levels of Fusarium toxins in organic grains and cereal products, if compared to conventional products. In conclusion, common practice in the organic sector (in particular, allowing sufficient time for transformation of manure; crop rotation) leads to food with similar or even lower levels of microbiological hazards and mycotoxins.
\end{abstract}

Keywords: organic food; food safety; enteric pathogens; antibiotic resistance; mycotoxins.

\section{Introduction}

In the last years, the organic food sector grew continuously in the European Union and many other parts of the world. Big retail chains and even discounters entered the organic market. As a consequence, quality managers of these businesses and of major suppliers representing strong but "vulnerable" brands - as represented in the "Consumer Goods Forum" of the Global Food Safety Initiative - have a strong interest to know whether organic products are as safe as conventional foods or whether special preventive measures should be taken to ensure their safety. Especially in U. S. and Canadian media, it has been speculated that keeping livestock outdoors, and the use of animal excreta for fertilization may result in elevated levels of microbiological hazards on organic foods. Therefore, the author of this article was requested to summarize current data on the safety of organic foods as compared to conventional foods. The present paper focuses on microbiological hazards including mycotoxins.

\section{Materials and Methods}

A literature survey was carried out by using literature databases (SCOPUS, Google Scholar), other reviews and data from official food inspection. Special attention was paid to peer-reviewed papers comparing organic with conventional foods.

\section{Results and Discussion}

\section{Bacterial pathogens on fresh produce}

In recent years, there is much concern about contamination of vegetables by zoonotic agents that may be present in organic fertilizers. Without doubt, manure (or human excreta) not stabilized by composting or anaerobic fermentation is a reservoir for enteric pathogens (FDA, 1998; Alsanius, 2014; Strawn et al. 2013). However, no increased levels of enteric pathogens or index organisms have been reported on organic produce (Table 1). This statement also applied to the prevalence of antibiotic resistance in plant-associated Enterobacteriaceae (van Hoek et al., 2013; Ruimy et al., 2010; Kim, Woo, 2014). Use of organic fertilizers according to good agricultural practice (GAP) does not increase the rate of contamination of fresh produce by enteric pathogens (Alsanius, 2014) or Escherichia coli (literature data summarized by Smith-Spangler et al., 2012). As learned from outbreaks and field studies, the main risk factors are use of irrigation water that had been contaminated by human or livestock excreta (Park et al., 2012), and handling of produce by carriers of pathogens, but not the farming system (Marine et al., 2015).

Some outbreaks have been reported in which leafy vegetables were shown or suspected to be involved (CDC, 2016). The 2006 outbreak of E. coli O157:H7 infections was linked to the consumption of bagged spinach. According to USDA documents (2007), the most likely cause was use of river water for irrigation that had been contaminated by excreta from cattle of a nearby farm, and of wildlife, with no evidence for the involvement of organic fertilizers. 


\section{Table 1}

Zoonotic agents in organic and conventional livestock and food of animal origin

\begin{tabular}{|c|c|c|}
\hline $\begin{array}{l}\text { Hazard and } \\
\text { sampling site }\end{array}$ & $\begin{array}{c}\text { Prevalence } \\
\text { organic vs. } \\
\text { conventional }\end{array}$ & References \\
\hline $\begin{array}{l}\text { Salmonella in pig } \\
\text { faeces at } \\
\text { slaughter }\end{array}$ & Equal or lower & $\begin{array}{l}\text { Bonde, } \\
\text { Sørensen, } 2007\end{array}$ \\
\hline $\begin{array}{l}\text { Salmonella in } \\
\text { poultry faeces at } \\
\text { slaughter }\end{array}$ & Equal or lower & $\begin{array}{l}\text { Van Loo et al., } \\
2012\end{array}$ \\
\hline $\begin{array}{l}\text { Campylobacter } \\
\text { in live poultry }\end{array}$ & Somewhat higher & $\begin{array}{l}\text { Heuer et al. } \\
2001 ; \\
\text { Hoogenblom et } \\
\text { al., } 2008\end{array}$ \\
\hline $\begin{array}{l}\text { Campylobacter } \\
\text { on poultry meat }\end{array}$ & About equal & $\begin{array}{l}\text { Van Loo et al., } \\
2012\end{array}$ \\
\hline $\begin{array}{l}\text { E. coli on beef } \\
\text { carcasses }\end{array}$ & About equal & $\begin{array}{l}\text { Smith-Spangler } \\
\text { et al., } 2012\end{array}$ \\
\hline $\begin{array}{l}\text { Toxoplasma } \\
\text { gondii in live } \\
\text { pigs }\end{array}$ & Higher & $\begin{array}{l}\text { Schulzig, } \\
\text { Fehlhaber, } 2006\end{array}$ \\
\hline
\end{tabular}

The E. coli O157:H7 outbreak due to Romaine lettuce, in 2013, was linked to the vicinity of cattle operations, too (Jung et al., 2014). The more recent outbreak of STEC (E. coli O26) infections at the Chipotle Mexican Grill Restaurants could not be linked to a particular food (CDC, 2016). Previously, this company made strong statements about health and sustainability. However, a view to the menu shown the Chipotle website shows that only few minor meal components (jalapeno, cilantro) were organic, and there is no indication for the involvement of fresh produce fertilized with fresh manure shortly prior to harvest.

Nevertheless, appropriate time intervals between application of manure and harvest are necessary (Mukherjee et al., 2007; Leifert et al., 2008; de Quadros Rodrigues et al., 2014; Park et al., 2014). Unstabilized (fresh, not composted or fermented) manure should (and is normally) only be applied in the year before planting vegetables (and other crops). The USDA Organic Rule requires 120 days between manure application and harvest, and standards issued by organisations such as the UK Soil Association are similar (Leifert et al., 2008). It should be remembered that use of farmyard manure is by no means restricted to organic systems, and properly managed soil and compost is a very hostile environment to enteric pathogens (Diez-Gonzalez, Mukherjee, 2009). This applies, in particular, to soils managed organically (Franz et al., 2008). Use of fresh manure only a few days before harvesting fresh produce is a serious violation of "good agricultural practice" but is very unlikely to happen in (organic or conventional) commercial practice. Such a treatment will not result in better yields, anyway, since time is missing to turn organic nitrogen into plant nutrients.

Other risk factors identified from outbreaks and field studies include irrigation with water contaminated with animal excreta, the presence of wildlife, weather (e.g. heavy rainfall and flooding) and handling of food by human carriers of pathogens. To quote from Marine et al. (2015), the farming system is not a food safety risk determinant for leafy greens.

\section{Bacterial pathogens in free-ranging livestock}

In organic agriculture, livestock has, within limits, access to "fresh air" outside the housing. Pigs and poultry kept outdoors may face a higher risk of exposure to zoonotic agents from the environment. Uncontrolled exposure to wildlife may result in serious losses due to parasites, other animal pathogens, and predators, and modern organic husbandry systems minimize these risks, also for economic reasons. Table 1 summarizes data on the prevalence of zoonotic agents in livestock and food of animal origin. The percentage of organic pigs carrying antibodies against Toxoplasma gondii tends to be higher in organic systems, with 9 and $2.5 \%$ of the animals ( $\mathrm{n}=200 \mathrm{each}$ ) found positive, respectively (Schulzig, Fehlhaber 2006). On the other hand, the prevalence of live salmonellae in fecal samples of pig and poultry at slaughter tends to be lower in organic pigs, indicating that organic pigs are less prone to be colonized by salmonellae (Leifert et al., 2008; Bonde, Sørensen, 2007). Campylobacter tends to be present more frequently in free-range chicken (Heuer et al., 2001, Hoogenbloom et al., 2008; Luangtongkum et al., 2006) but contamination rates on chicken meat were found to be similar, indicating the key role of cross-contamination during slaughter (van Loo et al., 2012). With respect to STEC, little if any difference in prevalence has been reported but there is some evidence that feeding more roughage (such as in organic farming) may reduce the prevalence of Shiga toxin forming E. coli (STEC) in cattle colons (DiezGonzalez, 2007). Generally speaking, however, contamination of carcasses and raw milk is mostly depending on the slaughtering and milking practice, respectively.

\section{Antibiotic-resistant bacteria}

Selection of antibiotic-resistant bacteria strains is one of the greatest problems in public health. Therefore, the levels of methicillin-resistant Staphylococcus aureus (MRSA) and of Enterobacteriaceae (in particular, E. coli) containing and expressing genes for extendedspectrum $\beta$-lactamases (ESBL) in raw materials and foods are monitored. The majority of studies indicate a lower prevalence of MRSA in organically reared pigs and on organic farms in general (Table 2). Organic poultry meat carried MRSA much less frequently than conventional poultry meat (Teramoto et al., 2016) whereas the contamination rates for ESBL-E. coli on organic poultry meat were reported to be similar (Kola et al., 2012; Cohen Stuart et al., 2012) or lower (Smith-Spangler et al., 2012). The lower prevalence of antibiotic-resistant bacteria on organic meat may be due to restrictions in the (therapeutic) use of antibiotics, of certain disinfectants (quaternary ammonium compounds, QAC), zinc, and to a higher resistance of the animals against colonization and infection 
(Slifierz et al., 2015). Again, the degree of contamination of meat by antibiotic-resistant bacteria strongly depends on slaughtering and butchering hygiene.

Table 2

Antibiotic-resistant bacteria in organic and conventional livestock and food of animal origin

\begin{tabular}{|c|c|c|}
\hline $\begin{array}{c}\text { Hazard and } \\
\text { sampling site }\end{array}$ & $\begin{array}{l}\text { Prevalence } \\
\text { organic vs. } \\
\text { conventional }\end{array}$ & References \\
\hline $\begin{array}{l}\text { MRSA }^{1} \text { in live } \\
\text { pigs and farm } \\
\text { environment }\end{array}$ & Lower & $\begin{array}{l}\text { Meemken, Blaha, } \\
\text { 2009, van de } \\
\text { Vijver et al., } 2014\end{array}$ \\
\hline $\begin{array}{l}\text { MRSA on } \\
\text { poultry meat }\end{array}$ & Lower & $\begin{array}{l}\text { Teramoto et al., } \\
2016\end{array}$ \\
\hline $\begin{array}{l}\mathrm{ESBL}^{2} \text { E. coli on } \\
\text { poultry meat }\end{array}$ & Equal or lower & $\begin{array}{l}\text { Smith-Spangler } \\
\text { et al., 2012; Kola } \\
\text { et al., 2012; Cohen } \\
\text { Stuart et al., } 2012\end{array}$ \\
\hline $\begin{array}{l}\text { Antibiotic- } \\
\text { resistant } \\
\text { Campylobacter } \\
\text { on poultry at } \\
\text { slaughter }\end{array}$ & Lower & $\begin{array}{l}\text { Luangtongkum et } \\
\text { al., } 2006\end{array}$ \\
\hline
\end{tabular}

${ }^{1}$ Methicillin-resistant Staphylococcus aureus

${ }^{2}$ Extended-spectrum- $\beta$-lactamase-positive

With regard to the presence of antibiotic resistance genes in plant-associated Enterobacteriaceae, little differences between organically and conventionally grown vegetables were reported (van Hoek et al., 2013; Ruimy et al., 2010; Kim, Woo, 2014).

\section{Fusarium toxins in grains and cereal products}

Fusarium toxins are, in low concentrations, frequently found in cereal products. Surveys clearly showed that restrictions in use of fungicides and insecticides do not lead to a higher prevalence of these toxins in cereal products (Edwards, 2009; Tangni et al., 2009). Seven studies analysed by Smith-Spangler et al. (2012) indicated lower contamination levels of these toxins in organic wheat while the study by Edwards (2009) did not report significant differences between levels in conventionally and organically grown wheat. When German-style bread (made from wheat and rye flour), sampled in 1999, was analysed for Fusarium toxins, levels were found to be lower in organic bread (Schollenberger et al., 2005).

Table 3 shows the results of some studies in Norway and Poland on Fusarium toxins in oats and rye. In Norway, toxin levels were significantly lower in organic oats while in Poland, only small differences were observed. Organic rye was found to contain lower levels of deoxynivalenol (DON) than did conventionally grown rye.

Various factors reduce the levels of Fusarium toxins in organically-growing grains (summarized by Benbrook, 2006): (i) Infection of the oars by Fusarium is difficult to control with fungicides, (ii) in organic agriculture, crop rotation reduces the level of inoculants, and (iii) restriction of nitrogenous fertilizers strengthens the defense mechanisms of the plants and improves the microclimate within the field. Moreover, cropping wheat immediately after maize, which, at least in Germany, is common practice in conventional but not in organic agriculture, favours infestation by Fusarium, resulting in higher levels of Fusarium toxins (Döll et al., 2002).

Table 3

Fusarium toxins in oats and rye ${ }^{1}$

\begin{tabular}{|c|c|c|c|c|c|}
\hline \multirow{2}{*}{$\begin{array}{c}\text { Cereal } \\
\text { and } \\
\text { origin }\end{array}$} & \multicolumn{2}{|c|}{$\mathrm{n}$} & \multirow{2}{*}{$\begin{array}{c}\text { Myco- } \\
\text { toxin }\end{array}$} & \multirow{2}{*}{$\begin{array}{c}\text { Results of } \\
\text { comparison }\end{array}$} & \multirow{2}{*}{$\begin{array}{l}\text { Refe- } \\
\text { rence }\end{array}$} \\
\hline & conv & org & & & \\
\hline $\begin{array}{l}\text { Oats, } \\
\text { Norway, } \\
2002-04\end{array}$ & 101 & 101 & $\begin{array}{l}\text { DON } \\
\text { NIV } \\
\text { HT-2 }\end{array}$ & $\begin{array}{l}\text { conv > org } \\
\text { conv }>\text { org } \\
\text { conv }>\text { org }\end{array}$ & (3) \\
\hline $\begin{array}{l}\text { Oats, } \\
\text { Poland, } \\
\text { 2006- } \\
2008\end{array}$ & 22 & 36 & $\begin{array}{l}\text { DON } \\
\text { NIV } \\
\text { HT-2 }\end{array}$ & $\begin{array}{l}\text { n. s. } \\
\text { n. s. } \\
\text { n. s. }\end{array}$ & (20) \\
\hline $\begin{array}{l}\text { Oats, } \\
\text { Poland, } \\
2009-11\end{array}$ & 24 & 34 & $\begin{array}{l}\text { DON } \\
\text { NIV } \\
\text { HT-2 }\end{array}$ & $\begin{array}{c}\text { n. s. } \\
\text { n. s. } \\
\text { conv > org }\end{array}$ & (36) \\
\hline $\begin{array}{l}\text { Rye, } \\
\text { Poland, } \\
2009-12\end{array}$ & 42 & 75 & $\begin{array}{l}\text { DON } \\
\text { NIV } \\
\text { HT-2 }\end{array}$ & $\begin{array}{c}\text { conv }>\text { org } \\
\text { n. s. } \\
\text { conv }>\text { org }\end{array}$ & (4) \\
\hline
\end{tabular}

${ }^{1}$ Abbreviations: DON, deoxynivalenol; NIV, nivalenol; HT-2, HT-2 toxin; conv > org, significantly higher levels in conventional grains that in organic grains.

\section{Conclusions}

Peer-reviewed studies do not support allegations that organic foods are more hazardous than conventional foods.

Modern outdoor systems for pigs and poultry, and organic fertilization using good agricultural practice do not increase risk.

However, the organic sector is advised not to raise unrealistic expectations among consumers in terms of safety, keeping in mind the (ever increasing) sensitivity of analytical methods, and communication should not raise.

Good management / manufacturing practice on farms and in processing is crucial for food safety, especially to avoid contamination of vegetables by enteric pathogens, and grains by toxigenic Fusarium strains.

\section{References}

1. Alsanius B. (2014) Mikrobiologiska faror I grönsakskedjan under primärproduktion. Sveriges Landbruksuniversitet (SLU), Landskapsarkitektur Trädgård Växtproduktionsvetenskap Rapport 2014:12. 73 pages (in Swedish). [accessed on 11 January 2017] Available at: http://pub.epsilon.slu.se/11325/

2. Benbrook C. M. (2006) Breaking the Mold: Impacts of organic and conventional farming systems on mycotoxins in food and livestock feed. [accessed on 11 January 2017] Available at: https://www.organiccenter.org/publications/breaking-the-mold-impacts-of- 
organic-and-conventional-farming-systems-onmycotoxins-in-food-and-livestock-feed/

3. Bernhoft A., Clasen P.-E., Kristoffersen A.B., Torp M. (2010) Less Fusarium infestation and mycotoxin contamination in organic than in conventional cereals. Food Additives and Contaminants - Part A Chemistry, Analysis, Control, Exposure and Risk Assessment, Vol. 27, p. 842-852.

4. Błajet-Kosicka A., Twarużek M., Kosicki R., Sibiorowska E., Grajewski J. (2014) Co-occurrence and evaluation of mycotoxins in organic and conventional rye grain and products. Food Control, Vol. 38, p. 61-66.

5. Bonde M., Sørensen, J.T. (2007) Salmonella infection level in Danish indoor and outdoor pig production systems measures by antibodies in meat juice and faecal shedding on-farm and at slaughter. In: "Animal health, animal welfare and biosecurity”, Proceedings no. 2, p. 729-734.

6. CDC (Centers for Disease Control and Prevention) (2016a) List of Selected Multistate Foodborne Outbreak Investigations. [accessed on 11 January 2017] Available at: https://www.cdc.gov/foodsafety/outbreaks/multistateoutbreaks/outbreaks-list.html

7. CDC (Centers for Disease Control and Prevention) (2016b) Multistate outbreaks of Shiga toxin-producing Escherichia coli O26 infections linked to Chipotle Mexican Grill restaurants (Final Update). [accessed on 11 January 2017] Available at: http://www.cdc.gov/ecoli/2015/o26-11-15/index.html.

8. Cohen Stuart J., van den Munckhof T., Voets G., Scharringa, J., Fluit, A., Leverstein-van Hall, M. (2012) Comparison of ESBL contamination in organic and conventional chicken meat. International Journal of Food Microbiology, Vol. 154, p. 212-214.

9. de Quadros Rodrigues R., Loiko M.R., Minéia Daniel de Paula C., Hessel C.T., Jacxsens L., Uyttendaele M., Bender R.J., Tondo E.C. (2014) Microbiological contamination linked to implementation of good agricultural practices in the production of organic lettuce in Southern Brazil. Food Control, Vol. 42, p. 152-164.

10. Diez-Gonzalez F. (2007) Organic livestock husbandry methods and the microbiological safety of ruminant production systems. In: Handbook of organic food safety and quality (eds. J. Cooper, U. Niggli, C. Leifert) p. 178198. Woodhead Publ., Cambridge, UK:

11. Diez-Gonzalez F., Mukherjee A. (2009): Produce Safety in Organic vs. Conventional Crops. In: Microbial Safety of Fresh Produce (ed. X. Fan, B.A. Niemira, C. Doona, F.E. Feeherry, R.B. Gravani), p. 81-99.

12. Döll S., Valenta H., Dänicke S., Flachowsky G. (2002) Fusarium mycotoxins in conventionally and organically grown grain from Thuringia/Germany. Landbauforschung Völkenrode, Vol. 2 (52), p. 91-96.

13. Edwards S.G. (2009) Fusarium mycotoxin content of UK organic and conventional wheat. Food Additives and Contaminants - Part A Chemistry, Analysis, Control, Exposure and Risk Assessment, Vol. 26, p. 496-506.

14. Franz E., Semenov A.V., van Bruggen A.H.C. (2008) Modelling the contamination of lettuce with Escherichia coli O157:H7 from manure-amended soil and the effect of intervention strategies. Journal of Applied Microbiology, Vol. 105 (5), p. 1569-1584.

15. Heuer O.E., Pedersen K., Andersen J.S., Madsen M. (2001) Prevalence and antimicrobial susceptibility of thermophilic Campylobacter in organic and conventional broiler flocks. Letters in Applied Microbiology, Vol. 33, p. $269-274$.
16. Hoogenboom L.A.P., Bokhorst J.G., Northolt M.D., van de Vijver L.P.L., Broex N.J.G., Mevius D.J., Meijs J.A.C., van der Roest J. (2008) Contaminants and microorganisms in Dutch organic food products: a comparison with conventional products. Food Additives and Contaminants, part A, Vol. 25 (10), p. 1195-1207

17. Jung Y., Jang H. Matthews K.R. (2014) Effect of the food production chain from farm practices to vegetable processing on outbreak incidence. Microbial Biotechnology, Vol. 7, p. 517-527.

18. Kim S., Woo G.-J. (2014) Prevalence and characterization of antimicrobial-resistant Escherichia coli isolated from conventional and organic vegetables. Foodborne Pathogens and Disease, Vol. 11, p. 815-821.

19. Kola A., Kohler C., Pfeifer Y., Schwab F., Kühn K., Schulz K., Balau V., Breitbach K., Bast A., Witte W., Gastmeier P., Steinmetz I. (2012) High prevalence of extended-spectrum- $\beta$-lactamase-producing Enterobacteriaceae in organic and conventional retail chicken meat, Germany. Journal of Antimicrobial Chemotherapy, Vol. 67, p. 2631-2634.

20. Kuzdraliński A., Solarska E., Mazurkiewicz J. (2013) Mycotoxin content of organic and conventional oats from southeastern Poland. Food Control, Vol. 33 (1), p. 68-72.

21. Leifert C., Ball K., Volakakis N., Cooper J.M. (2008) Control of enteric pathogens in ready-to-eat vegetable crops in organic and ,low input" production systems: a HACCP-based approach. Journal of Applied Microbiology, Vol. 105, p. 931-950.

22. Luangtongkum T., Morishita T.Y., Ison A.J., Huang S., McDermott P.F., Zhang O. (2006) Effect of conventional and organic production practices on the prevalence and antimicrobial resistance of Campylobacter spp. in poultry. Applied and Environmental Microbiology, Vol. 72, p. 3600-3607.

23. Marine S.C., Pagadala S., Wang F., Pahl D.M., Melendez M.V., Kline W.L., Oni R.A., Walsh C.S., Everts K.L., Buchanan R.L., Micallef S.A. (2015) The growing season, but not the farming system, is a food safety risk determinant for leafy greens in the Mid-Atlantic Region of the United States. Applied and Environmental Microbiology, Vol. 81 (7), p. 2395-2407.

24. Meemken D., Blaha T. (2009) Research on the occurrence of methicillin-resistant Staphylococcus aureus (MRSA) in domestic pigs and wild boars in Germany [Untersuchungen zum Vorkommen von Methicillinresistenten Staphylococcus aureus (MRSA) bei Haus- und Wildschweinen]. Deutsche Tierärztliche Wochenschrift, Vol. 116 (8), p. 297-301.

25. Mukherjee A., Speh D., Diez-Gonzalez F. (2007) Association of farm management practices with risk of Escherichia coli contamination in pre-harvest produce grown in Minnesota and Wisconsin. International Journal of Food Microbiology, Vol. 105, p. 296-302.

26. Park S., Szonyi B., Gautam R., Nightingale K., Anciso J., Ivanek R. (2012) Risk factors for microbial contamination in fruits and vegetables at the preharvest level: A systematic review. Journal of Food Protection, Vol. 75, p. 2055-2081.

27. Park W.-J., Ryu H.-Y., Lim G.-Y., Lee Y.-D., Park J.-H. (2014) Microbial prevalence and quality of organic farm produce from various production sites. Korean Journal of Food Science and Technology, Vol. 46 (2), p. 262-267.

28. Ruimy R., Brisabois A., Bernede C., Skurnik D., Barnat S., Arlet G., Momcilovic S., Elbaz S., Moury F., Vibet M.-A., Courvalin P., Guillemot D., Andremont A. (2010) Organic and conventional fruits and vegetables 
contain equivalent counts of Gram-negative bacteria expressing resistance to antibacterial agents. Environmental Microbiology, Vol. 12 (3), p. 608-615.

29. Schollenberger. M., Drochner W., Rüfle M., Suchy S., Terry-Jara H., Müller H.-M. (2005) Trichothecene toxins in different groups of conventional and organic bread of the German market. Journal of Food Composition and Analysis Vol. 18, p. 69-78.

30. Schulzig H.S., Fehlhaber K. (2006) Seroprävalenz von Toxoplasma gondii - Schweinefleisch und Schweinefleisch enthaltende Erzeugnisse aus konventioneller und ökologischer Herstellung. Fleischwirtschaft Vol. 86 (12), p. 106-108.

31. Slifietz M.J., Friendship R. M., Weese J. S. (2015) Methicillin-resistant Staphylococcus aureus in commercial swine herds is associated with disinfectant and zinc usage. Applied and Environmental Microbiology, Vol. 81, p. 2690-2695.

32. Smith-Spangler C., Brandeau M.L., Hunter G.E., Bavinger J.C., Pearson M., Eschbach P.J., Sundaram V., Liu H., Schirmer P., Stave C., Olkin I., Bravata D. M. (2012) Are organic foods safer and healthier than conventional alternatives? A systematic review. Annals of Internal Medicine, Vol. 157, p. 348-366.

33. Strawn L.K., Gröhn Y.T., Warchocki S., Worobo R.W., Bihn E.A., Wiedmann M. (2013) Risk factors associated with Salmonella and Listeria monocytogenes contamination of produce fields. Applied and Environmental Microbiology, Vol. 79, p. 7618-7627.

34. Tangni E.K., Pussemier L., Schneider Y.-J., Larondelle Y. (2013) Mycotoxins in organic and conventional cereals and derived products from Europe: A review [Mycotoxines dans les céréales et produits dérivés : Revue de la littérature sur les filières biologiques et conventionnelles en Europe] Cahiers Agricultures, Vol. 22 (3), p. 152-164.

35. Teramoto H., Salaheen S., Biswas D. (2016) Contamination of post-harvest poultry products with multidrug resistant Staphylococcus aureus in Maryland-Washington DC metro area. Food Control, Vol. 65, p. 132-135.

36. Twarużek M., Błajet-Kosicka A., Wenda-Piesik A., Pałubicki J., Grajewski J. (2013): Statistical comparison of Fusarium mycotoxins content in oat grain and related products from two agricultural systems. Food Control, Vol. 34 (2), p. 291-295.

37. USDA (Calvin, L.) (2007) Outbreak linked to spinach forces reassessment of food safety practices. [accessed on 11 January 2017] Available at: https://www.ers.usda.gov/amber-waves/2007/june/ outbreak-linked-to-spinach-forces-reassessment-of-foodsafety-practices/

38. van de Vijver L.P.L., Tulinski P., Bondt N., Mevius D., Verwer C. (2014) Prevalence and molecular characteristics of methicillin-resistant Staphylococcus aureus (MRSA) in organic pig herds in the Netherlands. Zoonoses and Public Health, Vol. 61 (5), p. 338-345

39. Van Hoek A. H. A. M., Veenman C. van Overbeek W., Lynch G., de Roda Husman A.M., Blaak H. (2015) Prevalence and characteristics of ESBL- and AmpCproducing Enterobacteriaceae on retail vegetables. International Journal of Food Microbiology, Vol. 204, p. $1-8$.

40. Van Loo E., Alali W., Ricke S.C. (2012) Food safety and organic meats. Annual Review of Food Science and Technology, Vol. 3, p. 203-225. 